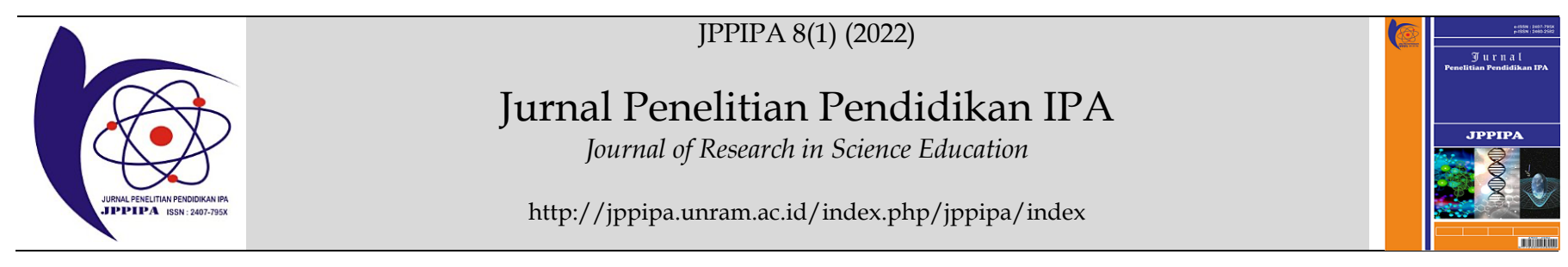

\title{
Improving Students' Critical Thinking Skills Against Environmental Problems: Practicum Mini Project "Understanding Public Perceptions of Environmental Problems"
}

\author{
Yusuf $^{*}$ \\ ${ }^{1}$ Department of Tadris IPA Biologi, Universitas Islam Negeri Mataram, Indonesia
}

DOI: $10.29303 /$ ippipa.v8i1.1224

\section{Article Info}

Received: December 9, 2021

Revised: January 10, 2022

Accepted: January 13, 2022

Published: January 31, 2022

\begin{abstract}
The purpose of this research is to improve students' critical thinking skills towards environmental problems through mini-project practicum activities on the concept of understanding public perceptions of environmental problems. This research is descriptive research using a qualitative approach. The subjects in this study were Semester II class E students who took Environmental Science courses in the Even Semesters of the 2019/2020 Academic Year. The instrument used to measure critical thinking skills using indicators developed by Ennis are 1) Elementary, 2) Clarification Basic Support, 3) Inference, 4) Advanced Clarification, 5) Strategies and Tactics. Results The average critical thinking ability of 20 students is in the medium category (average score of 69.54 ). Of the 20 students, $10 \%$ were in the very high category, $30 \%$ in the high category, $25 \%$ in the medium category, and 35\% in the low category. Indicators of students' critical thinking in 5 aspects, each of which has an average value that is in the medium category.
\end{abstract}

Keywords: Critical thinking skills; Environmental problems; Mini project practicum

\begin{abstract}
Citation: $\quad$ Yusuf, Y. (2022). Improving Students' Critical Thinking Skills Against Environmental Problems: Practicum Mini Project "Understanding Public Perceptions of Environmental Problems". Jurnal Penelitian Pendidikan IPA, 8(1), 209-215. https://doi.org/10.29303/jppipa.v8i1.1224
\end{abstract}

\section{Introduction}

Environmental problems are currently being discussed by various countries, both developed and developing countries such as Indonesia. Environmental problems that occur are the decreasing area of primary forests in the world and the problem of environmental pollution that triggers global warming and climate change (Katsoulakos, et al., 2016; Tuncay, et al., 2012). The current environmental development trend leads to negative things, namely severe ecosystem degradation, increasing climate change, and direct social impacts due to poverty and unemployment globally (Bell, 2016). Meanwhile, environmental management policies in a country are highly dependent on economic development and awareness of the importance of the environment (Katsoulakos, et al., 2016). Developed countries continue to press for developing countries that have extensive forests such as Indonesia and several countries in other tropical regions to continue to maintain their forests in order to remain sustainable. Based on the 2020 Yale Environmental Performance Index (EPI) report, Indonesia received an EPI score of 37.8 and was ranked 116th out of 180 countries, and is far from the position of several countries in the Southeast Asia region, namely Singapore (ranked 39), Brunei Darussalam (rank 46). , Malaysia (ranked 68), Thailand (ranked 78), and the Philippines (ranked 111) (Wendling, et al., 2020).

Indonesia is a developing country in the tropical region of Southeast Asia which in 2020 has a population of 270.20 million people (BPS-Statistics Indonesia, 2021a) and a GDP of 10,722.442.7 (billion rupiahs) (BPS-Statistics Indonesia, 2021b). Problems will occur if a large population is not accompanied by qualified skills and knowledge to work and resulting in a lot of unemployment and crime. The latest data shows that in 2019 the number of crimes reported in all 
regions in Indonesia amounted to 269,324 reports (BPSStatistics Indonesia, 2021b). Extensive forests will be disturbed due to local residents who do not have sufficient skills to survive and lack awareness of the importance of the environment (Castilho et al., 2018). Illegal logging often occurs in conservation forest areas where the perpetrators are local residents who are trying to survive illegal logging activities. Therefore, early solutions and preventive efforts are needed so that the environment and forests in Indonesia do not become critical due to the actions of several environmental destroyers.

The educational environment is a good means to teach students to be more aware of, aware of, and care about environmental problems (Edsand \& Broich, 2020; Hungerford \& Volk, 1990) and sustainable development (O'Flaherty \& Liddy, 2018). Environmental problems can start from small things such as the habit of littering both on the ground and in waters such as in ditches, rivers, and beaches. Through education in schools, especially in universities, is expected to be able to facilitate the creation of individuals who love and are aware of the environment and become problem-solvers for various environmental problems (Setyowati, et al., 2019). Environmental education aims not only to build knowledge but the most important thing is to build an attitude of caring for the environment from an early age (Arslan, 2012; Unesco, 1977). Educators play a strategic role in inserting environmental education into the school curriculum to prepare for the challenges that will be faced in the environment (Jacobi, 2005). Environmental education is ideological, does not arise naturally, so it needs a political role to implement it (Layrargues, 2000). Teachers and lecturers play an important role in teaching and instilling the important values of environmental education (Powers, 2004). Educational curricula both at the school level and at the tertiary level are expected to be able to produce graduates who are responsive to the issue of global warming and climate change originating from environmental pollution and illegal logging activities.

The ability to think critically is one of the abilities that today's students must possess, especially in terms of learning outcomes (Ermayanti \& Sulisworo, 2016). This is in line with the goals of 21st-century education, namely having critical thinking skills, problem-solving, collaboration, and communication skills (Akib \& Muhsin, 2019; Malik, 2018; Pacific Policy Research Center, 2010; Rizaldi, et al., 2020). The ability to think critically is not naturally owned by every individual but must be trained from an early age through the learning process from the school level to the lecture level (Rokayana, 2017). According to Lieung, et al. (2019), every human being has the potential to be able to think critically but not all humans are able to use it in various situations. Someone who has the ability to think critically will have the ability to analyze, be a problem solver and be able to make good decisions (Butler, 2012; Minott, et al., 2019). Assessment of critical thinking skills in higher education has received wide attention because of the increase in the level of assessment of learning outcomes for the better ( $\mathrm{Liu}$, et al., 2014).

The Tadris IPA Biology Study Program at the State Islamic University (UIN) Mataram has a curriculum that supports the Millennium Development Goals (MDGs) in the aspect of environmental sustainability, namely increasing insight and love for the environment and thinking critically about environmental problems. The Environmental Knowledge Course (Pengling) is one of the courses in the Biology Science Tadris Study Program which has an integrated and applicable Course Outcome (CPMK) and hones students' ability to think critically about environmental problems, namely: "Students are able to explain and analyze the basic concepts of Knowledge The environment, the flow of matter and energy and their interactions in ecosystems, environmental pollution, and global warming as well as ways to deal with pollution in the environment and predict the occurrence of natural disasters" (Team Biology Education Department, 2016). The practicum which was carried out during the Covid-19 pandemic was more emphasized on independent practicums around the house that hone critical thinking skills but still follow health protocols. This study aims to determine the effectiveness of a mini-project-based independent practicum around the house to improve critical thinking skills towards environmental awareness of students of the Biology Science Tadris Study Program, FTK UIN Mataram.

\section{Method}

This research method is descriptive using a qualitative approach. The location of this research is the Biology Science Tadris Study Program, Tarbiyah, and Teacher Training Faculty (FTK) State Islamic University (UIN) Mataram. The subjects in this study were Semester II class E students who took Environmental Science courses in the Even Semester of the 2019/2020 Academic Year, where learning was done online. Data collection techniques were carried out by observation and documentation. Students are given an assignment in the form of a mini-project with the title: Understanding Public Perceptions of Environmental Problems. The contents of the assignment consist of 2 (two) parts, namely first, students are assigned to look for environmental problems in the environment around their homes based on the results of observations and interviews with the community, in the second part students are assigned to formulate solutions to various 
environmental problems they find around their environment. The assignment of the mini project was carried out following the Covid-19 pandemic health protocol. Students' critical thinking skills are assessed from the results of student mini-project assignments collected through the Google Classroom (GC) application.

Students' critical thinking ability is measured using 5 indicators based on Ennis (1985), namely: 1) Building a simple explanation (Elementary Clarification), namely, 2) Building basic skills (Basic Support), 3) Drawing conclusions (Inference), 4) Further explanation (Advanced Clarification), and 5) Strategy and tactics (Strategies and Tactics). The scores for each category of critical thinking are shown in Table 1.

Table 1 Category of Critical Thinking Ability Score

\begin{tabular}{ll}
\hline Score & Category \\
\hline $81.25<\mathrm{X} \leq 100$ & Very high \\
$71.50<\mathrm{X} \leq 81,25$ & Tall \\
$62.50<\mathrm{X} \leq 71,50$ & Currently \\
$43.75<\mathrm{X} \leq 62,50$ & Low \\
$0<\mathrm{X} \leq 43,75$ & Very low \\
\hline
\end{tabular}

\section{Result and Discussion}

The results showed that through a mini-project task with the title: Understanding Public Perceptions of Environmental Problems, students became more critical of problems in the environment around their homes and were able to develop problem solvers. The results of one student's critical thinking activity in looking for environmental problems in the environment around his house are shown in Figure 1, while the results of one student's critical thinking in finding solutions to environmental problems can be seen in Figure 2. The results of the critical thinking assessment per indicator for 20 student's class II/E to environmental problems can be seen in Table 2 .

From Figure 1. it can be seen that students are trying to build a simple explanation about the state of the environment where they live in the form of an opinion about the condition of their area which is starting to improve. In the results of an interview with one of the informants, it was stated that the interviewee criticized the large number of people who littered, excessive use of private vehicles which caused congestion and air pollution. The resource persons also criticized the excessive felling of trees in the mountains. In Figure 2 it can be seen that the solution offered by one of the students as a result of critical thinking is not enough with words alone, but by directly planting trees and inviting the community to be involved in it.
Another deep ecology activity is working together to clean up the trash on the roads and ditches on the right day like Sunday and the right moment, namely the clean Friday program. In addition, the solution offered is to switch to the new normal in terms of environmental preservation, namely using shopping bags when going to the market or supermarket to reduce plastic waste.

\begin{tabular}{|l|}
\hline A. Community Responses on Environmental Problems \\
My Response \\
In my opinion, the environmental problems in my village have started to decrease from \\
before. At first the ditch was used as a garbage dump by some people. Currently \\
because of the activities carried out by the youth, namely mutual cooperation or \\
cooperation to clean the environment every Sunday. The environment in my area has \\
become cleaner. Most of the trash in the gutters is gone. And the increasing public \\
awareness to protect the environment, namely not to throw garbage in the gutter and \\
carelessly. however there are still a few people who are ignorant of the environmen \\
around them. \\
Resource Person 1 \\
Very concerned about the environment around me because there are still many \\
people...people who litter, even from the intellectual class though, not only that \\
excessive use of private motorbikes besides creating traffic jams on the road, the \\
amount of dirty air in my city is increasing increases, eventually creating pollution \\
Excessive felling of trees on land-mountain land. It's really very worrying and angry \\
because public awareness is still minimal towards environmental conservation \\
Figure 1. Display in Google Classroom the results of critical \\
thinking activities from a student's mini project task in \\
looking for environmental problems in the environment \\
around his house
\end{tabular}

carelessly will not make humans realize that it was wrong before feel the bad effects.

There are many ways to help people become aware, not only just words, but directly invites people to do things that can help protect the environment, such as planting trees, working together, cleaning the garbage on the street or cleaning the gutters which is usually done every Sunday or Friday (clean Friday) Don't use plastic bags when shopping, but use reusable shopping bags to reduce plastic bag trash.

Figure 2. Display in Google Classroom the results of critical thinking activities from a student's mini-project task in finding solutions to environmental problems in the environment around his home

From Table 2. it can be seen that the student's critical thinking skills as many as 2 people got a very high average score, 6 people got a high average score, 5 people got a medium average score, and 7 people got a low average score, with a total overall students get an average score of 69.54 (medium category). In Table 3 it can be seen that for all students, critical thinking skills on indicators of constructing simple explanations have an average score of 70 (medium category), indicators of building basic skills have an average score of 69.7 (medium category), indicators of drawing conclusions have scored an average of 70 (medium category), further explanation indicators have an average score of 67.7 (medium category), strategy and tactics indicators have an average score of 70.3 (medium category). 
Table 2. Results of Assessment of Critical Thinking for Class II/E Students on Mini Project Tasks: Understanding Public Perceptions of Environmental Problems

\begin{tabular}{|c|c|c|c|c|c|c|}
\hline \multicolumn{5}{|c|}{ Critical Thinking Value of Each Indicator } & \multirow[b]{2}{*}{ Average } & \multirow[b]{2}{*}{ Category } \\
\hline $\begin{array}{l}\text { Build asimple } \\
\text { explanation }\end{array}$ & $\begin{array}{l}\text { Building basic } \\
\text { skills }\end{array}$ & Conclusion & $\begin{array}{l}\text { Further } \\
\text { Explanation }\end{array}$ & $\begin{array}{l}\text { Strategy \& } \\
\text { Tactics }\end{array}$ & & \\
\hline 75 & 75 & 75 & 75 & 91 & 78.20 & high \\
\hline 61 & 61 & 61 & 61 & 61 & 61 & low \\
\hline 75 & 75 & 75 & 75 & 91 & 78.20 & high \\
\hline 91 & 91 & 91 & 75 & 91 & 87.80 & Very high \\
\hline 71 & 71 & 71 & 71 & 61 & 69 & Currently \\
\hline 65 & 65 & 65 & 65 & 65 & 65 & Currently \\
\hline 61 & 61 & 61 & 61 & 61 & 61 & low \\
\hline 61 & 61 & 61 & 61 & 61 & 61 & low \\
\hline 65 & 65 & 65 & 65 & 65 & 65 & Currently \\
\hline 91 & 91 & 91 & 91 & 91 & 91 & Very high \\
\hline 61 & 61 & 61 & 61 & 61 & 61 & low \\
\hline 61 & 61 & 61 & 61 & 61 & 61 & low \\
\hline 71 & 71 & 71 & 71 & 75 & 718 & high \\
\hline 91 & 85 & 91 & 61 & 65 & 78.60 & high \\
\hline 75 & 75 & 75 & 75 & 85 & 77 & high \\
\hline 75 & 75 & 75 & 75 & 75 & 75 & high \\
\hline 61 & 61 & 61 & 61 & 61 & 61 & low \\
\hline 61 & 61 & 61 & 61 & 61 & 61 & low \\
\hline 65 & 65 & 65 & 65 & 61 & 64.20 & Currently \\
\hline 63 & 63 & 63 & 63 & 63 & 63 & Currently \\
\hline
\end{tabular}

In general, students' critical thinking skills are in the medium category, while the results of the analysis of each indicator are shown in table 3.

Table 3. Average Score of Students' Critical Thinking Ability per Indicator

\begin{tabular}{lll}
\hline $\begin{array}{l}\text { Critical Thinking } \\
\text { Ability Indicator }\end{array}$ & Average Score & Category \\
\hline Build a simple & 70.00 & Currently \\
explanation & & \\
Building basic skills & 69.70 & Currently \\
Conclusion & 70.00 & Currently \\
Further explanation & 67.70 & Currently \\
Strategy \& Tactics & 70.30 & Currently \\
\hline
\end{tabular}

The results showed that the average critical thinking ability of students was in the medium category, where some of them were in the high category $(30 \%)$ and very high $(10 \%)$. These results indicate that the level of enthusiasm of students in carrying out mini project assignments is quite varied. Students who carry out mini project assignments seriously will be reflected in their critical thinking skills that reach the high - very high category, on the other hand, students who do not take assignments seriously will be reflected in the results of critical thinking skills in the medium -low category. This can be seen from the examination of student assignments, some of which copy-paste and take on the internet.

Critical thinking writing activities by students are largely determined by 2 factors, namely students' natural critical thinking abilities and students' critical thinking dispositions (Taube, 1997). Students who have good critical thinking skills will certainly be able to become good problem solvers (Butler, 2012; Lieung, et al., 2019). Through the mini-project task: Understanding Public Perceptions of Environmental Problems, students are invited to think critically about environmental problems around the area where they live. This task guides students to actively find out various things about environmental problems, ranging from household waste pollution in the form of plastic, kitchen waste, washing, and bathroom water which is directly dumped in ditches or ditches and rivers. This pollution is commonplace and is very easy to find in various housing areas, both in rural and urban areas. Various things that cause pollution, the result of critical analysis by students from the results of the mini-project is the lack of public awareness of the importance of protecting the environment where they live from pollution. In addition, pollution activities occur due to a lack of public knowledge of the dangers of pollution and a lack of community skills in processing waste or waste into useful and safe goods for the environment.

In critical thinking indicators: building a simple explanation (elementary clarification), students explain the state of pollution that occurs in the area where they live. This is based on direct observation activities carried out by students during their stay there. In this section, students also ask family members who are at home and ask community leaders around their neighborhood about environmental problems that occur. The information and arguments from the informants were then analyzed by students regarding the truth. Butler, et al. (2017) and Liu, et al. (2014) 
argues that critical thinking is stronger in predicting events in real life than relying on intelligence alone.

On the critical thinking indicator: building basic skills (basic support), students analyze the truth of the information from the informants and then immediately make observations to prove it. This will familiarize students to always check and clarify the information they have just obtained. This action certainly makes students' critical thinking power increase towards various phenomena that they get in the field, especially regarding environmental problems.

In critical thinking indicators: drawing conclusions (inference), students compose and consider deductions then make decisions and consider how the results will be. From various environmental phenomena and problems that he obtained from the speakers and the results of direct observations, students will immediately make a conclusion and formulate what actions they will take immediately. For example, from the results of several mini project assignments, students concluded that the main problem regarding environmental pollution they encountered was the lack of public awareness. In the aspect of decisions that will be made to overcome the problem, it must be precise and measurable how the impact and results will be achieved.

In critical thinking indicators: advanced clarification, students identify terms and consider definitions. From the various observations and findings that he obtained, the student finally found a definition or term that was appropriate for the phenomenon he found. Definitions or terms in environmental problems, for example from the results of student assignments, one student found the term "clean Friday" and the term "theory alone is not enough but the real action is needed" seen in Figure 3.

\footnotetext{
However, awareness that can create environmental sustainability is awareness by taking real actions or actions in the form of efforts that humans can take, such as not littering or also doing reforestation or re-greening,

This is because awareness without action will not restore nature that has been damaged by humans, or in other words, theory alone is not enough, but real action is needed. This action is a form of human concern for the natural environment so that in the future we can continue to keep it sustainable for the sake of coexistence (between humans and nature). ) better

Before realizing the environmental problems that occur, humans certainly have not felt the impact of the damage they have made. Throwing garbage carelessly, for example, will not make people realize that it is wrong until they feel the bad effects directly.
}

Figure 3. Students identify terms, one of the indicators of critical thinking.

In critical thinking indicators: strategies and tactics, students develop an appropriate solution for each problem that they get through field observations. The solution he got came from various literature that he studied and adapted to real conditions in the field and then developed a mature strategy. For example, in a mini-project created by a student, he found that environmental problems had occurred a long time ago and had been handled several times by the government and related parties in the form of socialization and projects that had been issued. However, after the socialization and the project was completed, environmental problems occurred again because there was no follow-up from the residents and the cost of maintaining the facilities that had been made.

Therefore, the solution offered by the students is that forming citizen awareness is the main thing. Higher education does not necessarily have a high awareness of the environment. People's mindsets that are wrong in handling the environment, especially regarding waste, must be changed slowly in order to form an environmentally conscious character like in developed countries. Reactivating local wisdom such as the Clean Friday program, which was pioneered by religious scholars and community leaders, will have a significant impact on solving existing environmental problems. Critical thinking is one of the most important skills for the success of university graduates in global job competition (Liu, et al., 2014).

\section{Conclusion}

From the results of the study, it can be concluded that giving a mini project practicum assignment regarding Understanding Public Perceptions of Environmental Problems has been able to improve the critical thinking skills of students of the Biology Science Tadris Study Program, FTK UIN Mataram, although it is not evenly distributed to all students. The average critical thinking ability of 20 students is in the medium category (average score of 69.54). Of the 20 students, $10 \%$ were in the very high category, $30 \%$ in the high category, $25 \%$ in the medium category, and $35 \%$ in the low category. Students' critical thinking indicators are in 5 aspects, each of which has an average value that is in the medium category. From the results of the miniproject, the initial and main problem of environmental pollution that must be resolved is the low public awareness to keep the environment clean.

\section{Acknowledgments}

This research and publication can be completed properly because of the support from the biology education study program at UIN Mataram

\section{References}

Akib, E., \& Muhsin, M. A. (2019). Assessment of Teaching in 21ST Century. Journal of Physics: Conference Series, $1179(1)$. https://doi.org/10.1088/1742- 
$6596 / 1179 / 1 / 012065$

Arslan, S. (2012). The Influence of Environment Education on Critical Thinking and Environmental Attitude. Procedia - Social and Behavioral Sciences, 55. https://doi.org/10.1016/j.sbspro.2012.09.579

BPS-Statistics Indonesia. (2021a). Hasil Sensus Penduduk 2020. In BPS-Statistics Indonesia (Vol. 6). Retrieved from: https://www.bps.go.id/website/materi_eng/mat eriBrsEng-20210121151046.pdf

BPS-Statistics Indonesia. (2021b). Statistical Yearbook of Indonesia 2021 (Sub-directorate of Statistical Compilation and Publication (ed.); Catalog: 1). BPS-Statistics Indonesia. Retrieved from: https://www.bps.go.id/publication/download.ht $\underline{\text { ml?nrbvfeve }=\ldots \text { MjAyMSOwMy0 }}$

Butler, H. A. (2012). Halpern critical thinking assessment predicts real-world outcomes of critical thinking. Applied Cognitive Psychology, 26(5). https://doi.org/10.1002/acp.2851

Butler, H. A., Pentoney, C., \& Bong, M. P. (2017). Predicting real-world outcomes: Critical thinking ability is a better predictor of life decisions than intelligence. Thinking Skills and Creativity, 25. https://doi.org/10.1016/j.tsc.2017.06.005

Castilho, L. C., De Vleeschouwer, K. M., MilnerGulland, E. J., \& Schiavetti, A. (2018). Attitudes and behaviors of rural residents toward different motivations for hunting and deforestation in protected areas of the northeastern atlantic forest, Brazil. Tropical Conservation Science, 11. https://doi.org/10.1177/1940082917753507

Edsand, H. E., \& Broich, T. (2020). The Impact of Environmental Education on Environmental and Renewable Energy Technology Awareness: Empirical Evidence from Colombia. International Journal of Science and Mathematics Education, 18(4). https://doi.org/10.1007/s10763-019-09988-x

Ennis, R. H. (1985). A Logical Basis for Measuring Critical Thinking Skills. In Educational Leadership. https://doi.org/10.3102/0034654310376953

Ermayanti, \& Sulisworo, D. (2016). Tingkat Kemampuan Berpikir Kritis Peserta Didik setelah Penerapan Model Pembelajaran Student Team Achievement Divisions (STAD) pada Siswa Sekolah Menengah Atas (SMA). Prosiding Seminar Nasional Quantum. Yogyakarta. Retrieved from: http:/ / eprints.uad.ac.id/7665/

Hungerford, H. R., \& Volk, T. L. (1990). Changing learner behavior through environmental education. Journal of Environmental Education, 21(3). https://doi.org/10.1080/00958964.1990.10753743

Jacobi, P. R. (2005). Environmental Education: the challenge of constructing a critical, complex and reflective thinking. Educação e Pesquisa, 31(2), 233250.
https://doi.org/https://doi.org/10.1590/S1517$\underline{97022005000200007}$

Katsoulakos, N., Misthos, L.-M., Doulos, I. G., \& Kotsios, V. (2016). Environment and Development_Chapter 8. In Stavros G. Poulopoulos \& Vassilis J. Inglezakis (Eds.), Elsavier. Elsevier B.V. https:// doi.org/10.1016/B978-0-444-627339.00008-3

Layrargues, P. P. (2000). Solving local environmental problems in environmental education: A Brazilian case study. Environmental Education Research, 6(2). https://doi.org/10.1080/713664670

Lieung, K. W., Rahayu, D. P., Fredy, \& Sulili, A. (2019). The influence of scientific approach on environmental problem solving skills in elementary school students. IOP Conference Series: Earth and Environmental Science, 343(1). https://doi.org/10.1088/1755-1315/343/1/012173

Liu, O. L., Frankel, L., \& Roohr, K. C. (2014). Assessing Critical Thinking in Higher Education: Current State and Directions for Next-Generation Assessment. ETS Research Report Series, 2014(1). https://doi.org/10.1002/ets2.12009

Malik, R. S. (2018). Educational Challenges In 21st Century And Sustainable Development. Journal of Sustainable Development Education and Research, 2(1). https://doi.org/10.17509/jsder.v2i1.12266

Minott, D., Ferguson, T., \& Minott, G. (2019). Critical Thinking and Sustainable Development. In Encyclopedia of Sustainability in Higher Education. https://doi.org/10.1007/978-3-319-63951-2_529-1

O'Flaherty, J., \& Liddy, M. (2018). The impact of development education and education for sustainable development interventions: a synthesis of the research. Environmental Education Research, 24(7).

https://doi.org/10.1080/13504622.2017.1392484

Pacific Policy Research Center. (2010). 21 ${ }^{\text {st }}$ Century Skills for Students and Teachers. Honolulu: Kamehameha Schools, Research \& Evaluation Division

Powers, A. L. (2004). Teacher Preparation for Environmental Education: Faculty Perspectives on the Infusion of Environmental Education Into Preservice Methods Courses. The Journal of Environmental Education, 35(3), 311. https:// doi.org/10.3200/JOEE.35.4.17-32

Rizaldi, D. R., Nurhayati, E., \& Fatimah, Z. (2020). The Correlation of Digital Literation and STEM Integration to Improve Indonesian Students' Skills in 21st Century. International Journal of Asian Education, https://doi.org/10.46966/ijae.v1i2.36

1(2).

Rokayana, N. (2017). Analisis Keterampilan Berpikir Kritis Siswa SMP Pada Mata Pelajaran IPA 
Ditinjau Dari Gaya Belajar Visual. SEJ (Science

Education Journal), 1(2), 84-91.

doi:http://doi.org/10.21070/sej.v1i2.1215

Setyowati, L., Sukmawan, S., \& El-Sulukiyyah, A. A. (2019). Using Environmental Issues To Trigger The Students' Critical Thinking In Essay Writing Class. J-ELLiT (Journal of English Language, Literature, and Teaching), $3(2)$. https://doi.org/10.17977/um046v3i2p17-26

Taube, K. T. (1997). Critical Thinking Ability and Disposition as Factors of Performance on a Written Critical Thinking Test. Journal of General Education, 46(2). Retrieved from: http://www.jstor.org/stable/27797335

Team Biology Education Department. (2016). Struktur Kurikulum Program Studi Tadris IPA Biologi Berbasis KKNI dan SNPT. In Department of Biology Education, FTK UIN Mataram. Department of Biology Education, FTK UIN Mataram.

Tuncay, B., Yilmaz-Tüzün, Ö., \& Teksoz, G. T. (2012). Moral reasoning patterns and influential factors in the context of environmental problems. Environmental Education Research, 18(4). https://doi.org/10.1080/13504622.2011.630576

Unesco. (1977). Intergovernmental Conference on Environmental Education. The Tbilisi Declaration, October.

Wendling, Z. A., Emerson, J. W., de Sherbinin, A., \& Esty, D. C. (2020). Yale Environmental Performance Index -2020. In New Haven, CT: Yale Center for Environmental Law \& Policy. epi.yale.edu 